\title{
KEANEKARAGAMAN ARTHROPODA PADA PERTANAMAN BAWANG MERAH DENGAN INTENSITAS APLIKASI PESTISIDA YANG BERBEDA DI KABUPATEN SIGI
}

\section{DIVERSITY OF ARTHROPODES IN ONION PLANTATION WITH DIFFERENT PESTICIDE APPLICATION INTENSITIES IN SIGI REGENCY}

\author{
Ratnawati $^{1}$, Kasman Jaya ${ }^{*}$ \\ ${ }^{1}$ Program Studi Agroteknologi Fakultas PertanianUniversitas Alkhairaat Palu \\ Jl. Diponegoro No. 39 Palu 94221 Sulawesi Tengah Indonesia
}

\begin{abstract}
ABSTRAK
Keanekaragaman hayati merupakan bagian penting dalam ekosistem pertanian (agroekosistem) dan keanekaragaman ditentukan oleh lingkungan dan aplikasi pestisida di lapangan. Penelitian tentang keanekaragaman arthropoda pada pertanaman bawang merah dengan intensitas aplikasi pestisida yang berbeda ini bertujuan untuk mengetahui jenis dan populasi arthropoda pada pertanaman bawang merah pada lahan yang diaplikasi pestisida dengan intensitas yang berbeda. Penelitian dilakukan di Desa Soulowe yang merupakan sentra tanaman bawang merah di Kabupaten Sigi yang aplikasi pestisidanya yang masif dan intensif, pada bulan Desember 2019 sampai Maret 2020. Pengambilan sampel dilakukan dengan metode mutlak (pengamatan langsung) dan metode nisbi (Pitffal Traf dan Jaring Ayun). Hasil identifikasi yang dilakukan di laboratorium Unisa dan Untad Palu ditemukan keanekaragaman arthropoda pada lahan intensitas aplikasi pestisida rendah lebih banyak dibandingkan dengan aplikasi sedang dan tinggi. Ada 7 ordo dan 13 famili yaitu Oxyopidae, Grillotalpidae (Ordo Araneae), Scarabaeidae, Coccinellidae (Ordo Coleoptera), Forficuloidea (Ordo Dermaptera), Agromyzidae, Muscidae (Ordo Diptera), Formicidae, Apidae (Ordo Hymenoptera), Noctuidae (Ordo Lepidoptera) dan Acrididae, Gryllidae danTotigonidae (Ordo Orthoptera). Tingkat keanekaragaman, kemerataan dan kekayaan famili serta kelimpahan inividu arthropoda lebih tinggi pada lahan dengan intensitas aplikasi pestisida rendah dibandingkan aplikasi pestisida sedang dan tinggi.
\end{abstract}

Katakunci: keanekaragaman, arthropoda, aplikasi pestisida, bawang merah

\begin{abstract}
Biodiversity is an important part of the agricultural ecosystem (agroecosystem) and diversity is determined by the environment and the application of pesticides in the field.. Research on the diversity of arthropods in shallot cultivation with different intensities of pesticide application aims to determine the types and populations of arthropods in shallot cultivation on land with different intensities of pesticide application. The research was conducted in the village of Soulowe, which is the center of shallot plants in Sigi Regency, with a massive and intensive application of pesticides, from December 2019 to March 2020. Sampling was carried out using absolute methods (direct observation) and relative methods (Pitffal Traf and Jaring Ayun). The results of the identification carried out in the Unisa and Untad Palu laboratories found that the diversity of arthropods in low-intensity areas of pesticide application was more than that of medium and high applications. There are 7 orders and 13 families, namely Oxyopidae, Grillotalpidae (Ordo Araneae), Scarabaeidae, Coccinellidae (Order Coleoptera), Forficuloidea (Order Dermaptera), Agromyzidae, Muscidae (Order Diptera), Formicidae, Apidae (Order of Hymenoptera), Noctuidae (Order of Hymenoptera) and Acrididae, Gryllidae andTotigonidae (Order Orthoptera). The level of diversity, evenness and family wealth as well as the abundance of arthropod individuals were higher in land with low pesticide application intensity than medium and high pesticide application.
\end{abstract}

Keywords: diversity, arthropods, pesticide application, and shallot

\footnotetext{
${ }^{*}$ Penulis Korespondensi.

E-mail: kasmanjsaad@yahoo.co.id

Telp: +62-81341025931
} 
Jurnal $C_{\text {zrotech }} 10$ (2) 54-59, Desember 2020

\section{Pendahuluan}

Keanekaragaman hayati merupakan bagian penting dalam ekosistem pertanian (agroekosistem) (Subagja, 1996), dan dalam keseimbangan ekosistem tanah (Fachrul, 2008). Keanekaragaman arthoropoda merupakan sumber daya dan bermanfaat sebagai penunjang hidup manusia karena ikut serta dalam memelihara biosfer (Subagja, 1996). Arthropoda sebagai salah satu komponen penting dalam ekosistem pertanian yang dapat digunakan sebagai salah satu indikator kualitas lingkungan pertanian yang berkelanjutan, selain sebagai bahan pertimbangan untuk pengelolaan OPT (Jaya,et al., 2015). Arthropoda juga berperan dalam perombakan bahan organik untuk menjaga kesuburan tanah, dengan demikian juga ikut menjaga berlangsungannya siklus hara dalam ekosistem pertanian (Pasaru, 2014). Arthropoda juga banyak berperan sebagai musuh alami baik sebagai predator maupun sebagai parasitoid. Namun peran arthropoda sebagai musuh alami di lapangan cukup terganggu akibat penggunaan pestisida yang begitu masif dan terus menerus dengan intensitas yang demikian tinggi.

Alasan petani bawang merah di desa Soulowe menggunakan pestisida, karena tingginya serangan Organisme Penganggu Tanaman (OPT) (Jaya, $d k k$.2019). Beberapa OPT bawang merah yang umum ditemukan di lapangan antara lain yang tergolong hama adalah: Orong-orong (Gryllotalpan spp), ulat grayak ( Spodoptera litura), ulat bawang (Spodoptera exiqua), lalat penggorok daun (Liriomyza chinensis), trips (Thrips tabaci). Sementara yang terinventarisasi dari golongan penyakit adalah: layu Fusarium ( Fusarium oxysporum) bercak ungu (Alternaria porri), Downey mildew (Peronospora destructor), Antraknose (Colletotrichum gloeosporiodes) dan Bercak Daun (Cercospora duddiae) (Rivai, 1995; Semangun, 1989; ). Upaya mengatasi serangan OPT dilakukan dengan penyemprotan pestisida secara masif dan terus menerus, meskipun secara konseptual penggunaan pestisida diposisikan sebagai alternatif terakhir dalam pengendalian hama serta dukungan dengan piranti peraturan yang mengikat. Oleh petani umumnya beralasan bahwa penggunaan pestisida adalah jaminan untuk terhindar dari kehilangan hasil akibat serangan OPT.

Akibat negatif dari penggunaan pestisida adalah timbulnya kekebalan (resistensi) hama, mendorong terjadinya resurgensi, terbunuhnya
e-ISSN : 2621-7236

p-ISSN : 1858-134X

musuh alami dan jasad non target, serta dapat menyebabkan terjadinya ledakan populasi hama sekunder (Oka,2005). Wali K.M. et al (2009) bahwa pestisida adalah senyawa kimia yang dapat membunuh semua jenis organisme yang tidak diinginkan untuk tetap menjaga peningkatan produksi pertanian. Selanjutnya Khan (2003) menyebutkan pula bahwa pestisida telah merusak keseimbangan alami pada tanah pertanian dan menyebabkan penurunan kelimpahan keanekaragaman hayati.

Konsep perlindungan tanaman hortikultura telah diarahkan kepada konsep Pengendalian Hama Terpadu (PHT). Suatu konsep pengendalian yang menitik beratkan pada pemanfaatan ekosistem yakni memperhatikan kondisi kelimpahan dan jumlah musuh alami di lapangan. Nilai keanekaragaman dan kemelimpahan arthropoda dalam ekosistem penting manfaatnya dalam pengelolahan hama terpadu. Olehnya guna mendukung konsep PHT tersebut maka dilakukan penelitian untuk mendapatkan informasi tentang keanekaragaman arthropoda pada lahan pertanaman bawang merah di Soulowe dengan intensitas penggunaan pestisida yang berbeda. Penelitian bertujuan untuk mengetahui jenis dan populasi arthropoda pada pertanaman bawang merah pada lahan yang diaplikasi pestisida dengan intensitas yang berbeda.

\section{Metode}

\section{Tempat dan Waktu}

Penelitian ini telah dilakukan, Desa Soulowe Kecamatan Sigi Biromaru Kabupaten Sigi untuk pengambilan sampel arthropoda. Identifikasi dilaksanakan di Laboratorium Unisa dan Untad Palu. Penelitian dimulai dari bulan Desember 2019 sampai dengan Maret 2020.

\section{Bahan dan Alat}

Bahan yang digunakan dalam penelitian ini adalah; alkohol 70\%, deterjen dan Akuades. Alat yang digunakan adalah; kuas kecil,pinset, tisu, spidol, kertas label, plastik klip, alat tulis, botol pembunuh, jaring ayun, Pitfall traf, buku indentifikasi,mikroskop dan kamera.

\section{Penetuan Lokasi}

Penentuan lokasi pada pertanaman bawang merah di Soulowe, diawali dengan kegiatan survey dengan menggunakan instrument kuesioner yang telah disediakan. Tahapan ini dimaksudkan untuk memperoleh data tentang aplikasi pestisida per musim panen tanaman 


\section{Jurnal agrotech $_{10}$ (2) 54-59, Desember 2020}

bawang merah dan selanjutnya diperoleh data mengenai lahan kategori rendah, sedang dan tinggi aplikasi pestisidanya. Penentuan sampel petani dilakukan secara acak dengan didasarkan jumlah petani bawang merah di Soulowe yaitu $289 \mathrm{KK}$, sehingga diperoleh 30 jumlah responden atau $10 \%$ dari jumlah petani. Selanjunya diperoleh 5 orang petani yang hanya menggunakan herbisida dan menggunakan pestisida nabati dalam pengendalian hama dan penyakit selanjutnya diketergorikan rendah. 12 orang petani mengaplikasi pestisida kurang atau sama dari 10 kali permusim tanam selanjutnya diketegorikan sedang dan 13 orang petani mengaplikasi pestisida lebih dari 10 kali permusim tanam selanjutnya diketegorikan tinggi.

\section{Metode Pengambilan sampel}

Pengambilan sampel dilakukan secara mutlak (pengamatan langsung) dan pengamatan nisbi (Pitfall Trap dan Jaring Ayun) pada umur tanaman 21 HST, setelah itu pengambilan sampel dilakukan setiap minggu di lahan pertanaman bawang merah sampai sebelum panen pada masing-masing lahan petani bawang merah yang telah dikelompokkan rendah, sedang dan tinggi.

\section{Parameter yang Diamati}

Arthropoda yang diamati dan terperangkap diamati jenis dan jumlah arthropoda serta perannya pada pertanaman bawang merah.

\section{Analisi Data}

Data yang diperoleh di analisis dengan :

a. Indeks keanekargaman (H') ShannomWinner (Krebs, 2000)

$$
\begin{aligned}
& \mathrm{H}=-\sum_{k=1}^{n} \mathrm{Pi}(\ln \mathrm{pi}) \\
& \mathrm{Pi}=\mathrm{n} / \mathrm{N}
\end{aligned}
$$

Keterangan:

$\mathrm{H}=$ Indeks keanekaragaman

$\mathrm{Pi}=$ Proporsi spesies ke-i dalam komunitas

$\mathrm{n}=$ Kelimpahan individu morfospesies

$\mathrm{N}=$ Jumlah Total individu semua spesies
e-ISSN : 2621-7236

p-ISSN : 1858-134X

b. Indeks kemerataan morfospesies Simpson's (Krebs, 2000);

$$
\mathrm{D}=1-\sum_{\mathrm{k}=1}^{\mathrm{n}} \mathrm{Pi}^{2}
$$

Keterangan:

D= Indeks kemerataan Simpson's

$\mathrm{Pi}=$ Proporsi individu morfospesies ke $\mathrm{i}$

\section{Hasil dan Pembahasan}

Berdasarkan pengamatan dan identifikasi terhadap ordo, famili dan individu yang ditemukan pada lahan pertanaman bawang merah dengan intensitas aplikasi pestisida yang berbeda dapat dilihat pada tabel 1 .

Keanekaragaman arthropoda yang ditemukan pada lahan yang aplikasi pestisida rendah lebih banyak dibandingkan dengan aplikasi sedang dan tinggi. Jumlah ordo dan Famili yang ditemukan aplikasi pestisida rendah terdiri dari 7 ordo dan 13 famili yaitu Oxyopidae, Grillotalpidae (Ordo Araneae), Scarabaeidae, Coccinellidae (Ordo Coleoptera), Forficuloidea (Ordo Dermaptera), Agromyzidae, Muscidae (Ordo Diptera), Formicidae, Apidae (Ordo Hymenoptera), Noctuidae (Ordo Lepidoptera) dan Acrididae, Gryllidae danTotigonidae (Ordo Orthoptera). Arthropoda yang ditemukan berperan sebagai parasit ada 7 famili dan 6 famili sebagai predator. McNaughton \& Wolf (1998) mengemukakan bahwa keragaman merupakan prinsip lingkungan yang dapat diterapkan dalam kerangka perlindungan tanaman. Dalam suatu ekosistem alami, fungsi pengaturan yang terjadi merupakan produk keragaman.

Penggunaa pestisida yang berlebihan tidak hanya mematikan serangga parasit, namun juga serangga bermanfaat. Pada penelitian ini ordo Coleoptera famili Coccinellidae dan Ordo Dermaptera yang merupakan predator tidak ditemukan pada aplikasi pestisida tinggi. Hal ini disebabkan karena tingginya intensitas aplikasi pestisida yang digunakan petani. Menurut Oka (2005) pestisida memberi dampak negatif bagi organisme bermanfaat seperti matinya musuh 
Tabel 1. Jenis dan Jumlah Arthropoda pada Pertanaman Bawang Merah

\begin{tabular}{|c|c|c|c|c|c|c|}
\hline \multirow{2}{*}{ Ordo } & \multirow{2}{*}{ Famili } & \multirow{2}{*}{ Paranan } & \multicolumn{3}{|c|}{ Aplikasi } & \multirow{2}{*}{ Jumlah } \\
\hline & & & Rendah & Sedang & Tinggi & \\
\hline \multirow[t]{2}{*}{ Araneae } & Oxyopidae & Predator & 19 & 2 & 4 & 25 \\
\hline & Grillotalpidae & Parasit & 5 & 3 & 0 & 8 \\
\hline \multirow[t]{2}{*}{ Coleoptera } & Scarabaeidae & Predator & 7 & 4 & 3 & 14 \\
\hline & Coccinellidae & Predator & 2 & 2 & 0 & 4 \\
\hline Dermaptera & Forficuloidea & Predator & 6 & 3 & 0 & 9 \\
\hline \multirow[t]{2}{*}{ Diptera } & Agromyzidae & Parasit & 5 & 19 & 1 & 25 \\
\hline & Muscidae & Parasit & 4 & 1 & 3 & 8 \\
\hline \multirow[t]{2}{*}{ Hymenoptera } & Formicidae & Predator & 65 & 53 & 34 & 152 \\
\hline & Apidae & Predator & 4 & 2 & 1 & 7 \\
\hline Lepidoptera & Noctuidae & Parasit & 17 & 5 & 2 & 24 \\
\hline \multirow[t]{4}{*}{ Orthoptera } & Acrididae & Parasit & 19 & 11 & 1 & 31 \\
\hline & Gryllidae & Parasit & 5 & 3 & 0 & 8 \\
\hline & Totigonidae & Parasit & 1 & 0 & 1 & 2 \\
\hline & Jumlah & & 159 & 108 & 50 & 317 \\
\hline
\end{tabular}

alami. Penelitian yang dilaksanakan Novri $d k k$. 2015 membuktikan hal yang sama bahwa ketergantungan petani pada pengendalian tunggal, dengan pestisida telah menyebabkan

rendahnya keragaman musuh alami (predator dan parasitoid) pada lahan bawang merah. Pestisida menduduki posisi yang unik diantara berbagai bahan kimia yang kita temui sehari-hari karena senyawa golongan ini dengan sengaja "ditumpahkan" kelingkungan dengan maksud membunuh suatu kehidupan yang tidak dikehendaki.

Keberadaan ordo Diptera famili Agromyzidae yang berperan sebagai parasit (hama) pada pertanaman bawang merah yang jumlah individu ditemukan lebih banyak pada intensitas aplikasi pestisida sedang dibandingkan aplikasi rendah (Tabel 1), menunjukkan kemungkinan terjadinya resistensi hama pada aplikasi pestisida bawang merah di Soulowe. Menurut Oka (2005), dampak dari pestisida adalah timbulnya kekebalan (resistensi) hama. Hal yang sama dikemukakan oleh Untung (2006), banyak spesies hama telah menjadi tahan atau resisten terhadap satu atau beberapa jenis pestisida. Serangga merupakan organisme yang memiliki respons yang sangat cepat akan adanya perubahan ekosistem. Serangga juga memiliki kemampuan untuk mengatasi berbagai tekanan yang terjadi di lingkungan yang menghalanginya, termasuk pengendalian dengan memanfaatkan insektisida. Hal ini juga menyebabkan petani semakin sering mengaplikasikan pestisida untuk mengendalikan OPT. Penelitian Arfan $d k k$ (2016) di Lembah Palu menunjukkan bahwa adanya peningkatan serangan Liriomyza spp. seiring peningkatan aplikasi pestisida di lapangan.

Selanjutnya analisis komunitas arthropoda pada pertanaman bawang merah di Soulowe dapat dilihat pada Tabel 2.

Tabel 2. Analisis Komunitas Arthropoda secara Komulatif

\begin{tabular}{lccc}
\hline & \multicolumn{3}{c}{ Aplikasi } \\
\cline { 2 - 4 } & Rendah & Sedang Tinggi \\
\hline Indeks & 1,93 & 1,59 & 1,31 \\
Keanekaragaman & 0,77 & 0,69 & 0,51 \\
Indeks Kemerataan & 7 & 7 & 6 \\
Kekayaan Ordo & 13 & 12 & 9 \\
Kekayaan Famili & 159 & 108 & 50 \\
Kelimpahan Individu & & & \\
\hline
\end{tabular}

Hasil penelitian ini juga menunjukkan bahwa indeks keanekaragaman, indeks kemerataan, kekayaan ordo, famili serta kelimpahan individu lebih tinggi pada aplikasi pestisida rendah dibandingkan aplikasi pestisida sedang dan tinggi. Penggunaan pestisida secara berlebihan telah terbukti memberi dampak negatif bagi keanekaragaman arthropoda. Keberadaan arthropoda dari aspek keragaman dan kelimpahan menjadi sangat penting yang juga merupakan atribut yang khas dimiliki suatu komunitas biotik (McNaughton \& Wolf. 1998). Altieri,A.A dan C.J. Nicholls. (2004), mengemukakan bahwa dengan semakin tingginya tingkat keanekaragaman arthropoda dilokasi, maka populasi jenis arthropoda di lokasi tersebut lebih seimbang, sehingga diperkirakan tingkat serangan hama akan semakin kurang. Fakta di lapangan juga menunjukkan serangan OPT pada lahan aplikasi rendah dan sedang lebih sedikit. 
Jurnal Agrotech 10 (2) 54-59, Desember 2020

Menurut Untung (2006) keragaman dapat digunakan untuk memperbaiki pengendalian hama dan penyakit. Keanekaragaman artropoda dalam suatu ekosistem mempunyai arti yang sangat penting sebagai sumber daya dan sebagai pemelihara ekosistem serta pemelihara keanekaragaman spesies. Suatu agroekosistem akan stabil apabila keanekaragamannya terjaga, terpenuhi kestabilannya bila penggunaan pestisida dibatasi atau dihentikan. O'Brien (1978) mengemukakan bahwa ledakan hama yang terjadi di ekosistem dapat disebabkan karena terjadi perubahan komunitas, dari komunitas alami yang mempunyai diversitas tinggi berubah menjadi komunitas yang mempunyai diversitas yang rendah.

\section{Kesimpulan}

1. Penggunaaan pestisida oleh petani bawang merah di lapangan mempengaruhi keanekaragaman arthropoda.

2. Aplikasi pestisida rendah, arthropoda yang ditemukan lebih banyak jenis dan ragamnya dibandingkan dengan aplikasi sedang dan tinggi. Ada 7 ordo dan 13 famili yaitu Oxyopidae, Grillotalpidae (Ordo Araneae), Scarabaeidae, Coccinellidae (Ordo Coleoptera), Forficuloidea (Ordo Dermaptera), Agromyzidae, Muscidae (Ordo Diptera), Formicidae, Apidae (Ordo Hymenoptera), Noctuidae (Ordo Lepidoptera) dan Acrididae, Gryllidae danTotigonidae (Ordo Orthoptera).

3. Tingkat keanekaragaman, kemerataan dan kekayaan famili serta kelimpahan inividu arthropoda lebih tinggi pada lahan dengan intensitas aplikasi pestisida rendah dibandingkan lahan pertanaman bawang merah aplikasi pestisida sedang dan tinggi

\section{Daftar Pustaka}

Altieri,A.A and C.J. Nicholls. 2004. Biodiversity and Pest Managemnet in Agroecosystem, Food Products Press. New York.

Arfan, Ratnawati dan Sahabuddin. 2016. Jenis dan Penyebaranb Liriomyza, spp. Pada Sentra Penanaman Bawang Merah Di Lembah Palu. Prosiding Seminar PEI.Palu.

Fachrul,N.F.2008. Metode Sampling Bioekologi. Bumi Aksara.Jakarta.
e-ISSN : 2621-7236

p-ISSN : 1858-134X

Khan,M.Z. 2003. Effect of pesticides on biodiversity: comparison of malathion with biosal on protein contents in Calotes versicolor. J.nat. hist.wildl. Vol. 2, N0.1 : 25-28

Krebs, C.J.2000. Program for Ecological Methodology (Software) Second Edition. New York; An Print of Addison Wesley Longman, Inc.

Jaya,K., Muhammad Ardi, Sylvia Sjam dan Gufran D.D., 2015. Onion Farmers Behavior In Ecosystem-Based Pest (EBP) Control In Sigi District Of Central Sulawesi Province. Man In India, 95:649-659 .SerialPublication.

Jaya,K., Sayani, Ratnawati, Rastam. 2019. Hubungan Antara Faktor Sosial Demografi Dengan Perilaku Petani Dalam Mengaplikasi Pestisida (Kasus Pada Petani Bawang Merah Di Kecamatan Biromaru Kabupaten Sigi). Jurnal Agrotech 10 (1) 27-34.

McNaughton \& Wolf. 1998. General Ecology. Second Edition. CBS Educational and Professional Publishing, a Division of CBS Inc., 383 Medison Avenue, New York, N.Y. USA.

Novri N., Reflinaldo, Kartika.,A. 2015. Keragaman Predator dan Parasitoid pada Pertanaman Bawang Merah: Studi Kasus di Daerah Alahan Panjang, Sumatera Barat. Prosiding Seminar Nasional Masyarakat. Biodiversiti Indonesia. Vol 1. Nomor 5 Agustus 2015.

O'Brien, R.D. 1978. Integrated Pests Management: A biological Viewpoint.In E.H. Smith and D.Pimentel (Eds) Pest Control Strategies.Academic Press. New York

Oka Ida Nyoman. 2005. Pengendalian Hama Terpadu dan Implementasinya di Indonesia. Yogyakarta: Gadjah Mada University Press.

Pasaru,F., 2014. Keanekaragaman Arthropoda dan Cendawan Sebagai Agensia Hayati Helopeltis spp (Hemiptera : ) pada Berbagai Sistem Pertanaman Kakao. Disertasi Universitas Tadulako, Palu. 
Jurnal Cgrotech 10 (2) 54-59, Desember 2020

Rivai, M.A, 1995. Keanekaragaman Jamur di Sekitar Kita (Sebuah Pengantar Mikologi Tropik).Lembaga Ilmu Pengetahuan Indonesia dan Gadjah Mada University Press, Yogyakarta.

Semangun, H. 1989. Penyakit-Penyakit Tanaman Hortikultura di Indonesia.Gadjah Mada University Press, Yogyakarta.

Subagja,J., 1996. Prinsip Keanekaragaman Hayati dalam Ekosistem.Prosiding
e-ISSN : 2621-7236

p-ISSN : 1858-134X

Makalah Utama Seminar Nasional Pengendalian Hayati.UGM Yogyakarta.

Untung,K.2006. Pengantar Pengelolaan Hama Terpadu. Gadjah Mada Yogyakarta : University Press.

Wali, K.M., Falih Envrendilek \& M.Siobhan Fennesy. 2009. The Environment Science, Issue add Solutions. CRC Press,Taylor\& Farncis Group. Boca Raton. 